\title{
Bovine Erythrocyte Fractionation in Percoll Density Gradients
}

Ryuji ASANO, and Shigeo HOKARI

Department Veterinary Pharmacology, College of Agriculture and Veterinary Medicine, Nihon University, Kameino, Fujisawa 252, Japan

(Received 20 November 1986/Accepted 20 March 1987)

Jpn. J. Vet. Sci. 49(3): 575-576, 1987

KEY WORDS: age-dependent fraction, bovine erythrocyte, percoll.

Age-dependent fractionation of erythrocytes has been accomplished using density gradient with a variety of supporting media such as bovine serum albumin $[7,10]$, Stractan II $[4,9]$, phthalate esters [5] and dextran [6]. However, uses of serum albumin and Stractan II are technically complicated and expensive to prepare, phthalate esters are nonmiscible with water and damage the erythrocytes, and dextran causes the erythrocyte agglutination. Further, all of these methods, except those employing phthalate esters, require prolonged centrifugqation. These disadvantages have been overcome by using Percoll (Pharmacia Fine Chemicals, Uppsala, Sweden), a commercially available polyvinyl-pyrrolidone-coated colloidal silica [11]. This method offers the advantages such as simplicity of preparation, economy, controllable osmolarity, low viscosity, and nonagglutination of erythrocytes, and this method has been applied to the fractionation of a population of human erythrocytes according to

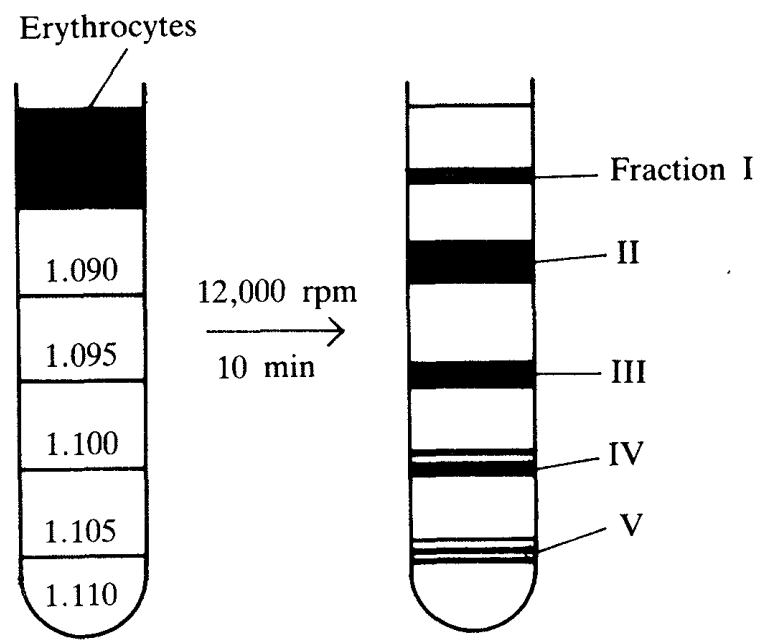

Fig. 1. Bovine erythrocytes were centrifuged at $12,000 \mathrm{rpm}$ for $10 \mathrm{~min}$ on five Percoll layers having the specific gravities (top to bottom) of 1.090, 1.095, $1.100,1.105$ and 1.110 . The cells were separated into five fractions. age [14]. The present report describes the method to fractionate bovine erythrocytes by centrifugation through discontinuous density gradients of Percoll. The activities of several enzymes as indications of erythrocyte age in each fraction are also determined.

Blood samples were collected from healthy Holstein Friesian cows into Alsever's solution. White cells were completely removed by passing the blood through an $\alpha$-cellulose: microcrystalline cellulose $(2: 1 \mathrm{w} / \mathrm{w})$ column in acid-citratedextrose (ACD) medium as described by Beutler et al . [2]. The filtered erythrocytes were washed three times with ACD. After the final washing the cells were resuspended in ACD to make a packed cell volume of $25 \%$ and stored at $4{ }^{\circ} \mathrm{C}$ until use.

The fractionation of of the erythrocytes was achieved by a density layer centrifugation technique using solutions of Percoll. Five dilution steps of Percoll were made with $0.15 \mathrm{M} \mathrm{NaCl}$ solution to make specific gravities of $1.090,1.095,1.100$, 1.105 and 1.110 at $20^{\circ} \mathrm{C}$. Approximately $2 \mathrm{ml}$ of each of these Percoll solutions was poured to form layers in a 15-ml glass centrifuge tube, starting with the highest specific gravity on the bottom. Three ml of the erythrocyte suspension were carefully layered over the top of the five Percoll layers and centrifuged in the Kubota

Table 1. Enzyme activities in bovine erythrocyte fractions separated in Percoll gradients

\begin{tabular}{lcrc}
\hline RBC fraction & G6PD $^{\mathrm{a})}$ & $\mathrm{PK}^{\mathrm{b})}$ & $\mathrm{LDH}^{\mathrm{c})}$ \\
\hline Unseparated & $6.02 \pm 1.89^{\mathrm{d})}$ & $14.89 \pm 2.37$ & $22.78 \pm 4.44$ \\
Fraction I & $9.64 \pm 2.40$ & $20.05 \pm 5.26$ & $29.33 \pm 3.06$ \\
II & $7.09 \pm 1.98$ & $15.26 \pm 4.10$ & $22.50 \pm 1.67$ \\
III & $5.55 \pm 1.52$ & $11.68 \pm 3.63$ & $16.67 \pm 2.51$ \\
IV & $3.96 \pm 1.25$ & $8.42 \pm 2.16$ & $14.17 \pm 0.83$ \\
V & $4.36 \pm 1.86$ & $9.74 \pm 2.10$ & $12.12 \pm 1.33$
\end{tabular}

a) Glucose-6-phosphate dehydrogenase.

b) Pyruvate kinase.

c) Lactate dehydrogenase.

d) Units per g of hemoglobin [1]; mean \pm SD of eight experiments. 
KR-20000T centrifuge in the RA-3 rotor at $12,000 \mathrm{rpm}$ for $10 \mathrm{~min}$ at $4^{\circ} \mathrm{C}$. After centrifugation, five fractions (Fractions I- V from top to bottom) of the erythrocytes were formed on the top of five Percoll layers (Fig. 1).

The age-dependent distribution of the erythrocytes in each fraction was ascertained by the determination of the activities of three agedependent enzymes, glucose-6-phosphate dehydrogenase (G6PD, EC 1.1.1.49), pyruvate kinase (PK, EC 2.7.1.40) and lactate dehydrogenase (LDH, EC 1.1.1.27) [12]. Each cell fraction was removed from the tube with a capillary pipette, and cells were carefully washed three times with $0.15 \mathrm{M} \mathrm{NaCl}$ to remove Percoll. After the final washing, the cells were resuspended in ACD and the packed cell volume was adjusted to $50 \%$. The activities of G6PD, PK and LDH were determined spectrophotometrically by the method of Beutler et al. [1]. Results were expressed as units per gram of hemoglobin because the hemoglobin content in the erythrocyte does not change along with cell aging [9].

The activities of G6PD, PK and LDH decreased successively from the top to the bottom fractions of erythrocytes separated in Percoll gradients (Table 1). In human erythrocytes, it has been shown that the activities of G6PD and PK decrease dramatically in the higher density fractions [3, 13]. Correlation between the age of erythrocyte and enzyme activity has been observed to occur in other animal species. In sheeps, it has been noted that the activities of G6PD and hexokinase, but not PK, decrease consistently with cell age [8]. Therefore, the results of the present study are consistent with the previous results although the changes in the enzyme activity in bovine erythrocytes with different specific activity were not so great as those reported in human erythrocytes.
In conclusion, the method described in the present report is simple enough to adapted for clinical diagnostic purposes. Further, the quantities of erythrocytes separated are sufficient for studying the physicochemical and biochemical properties of erythrocytes at different ages.

\section{REFERENCES}

1. Beutler, E., Blume, K.G., Kaplan, J.C., Löhr, G.W., Rannot, B., Valentine, W.N. 1977. Brit. J. Haematol. 35: 331-340.

2. Beutler, E., West, C., and Blume, K.G. 1976. J. Lab. Clin. Med. 88: 328-333.

3. Chapman, R., and Schaumburg, L. 1967. Brit. J. Haematol. 13: 665-678.

4. Corash, L.M., Piomelli, S., Chen, H.C., Seaman, C., and Gross, E. 1974. J. Lab. Clin. Med. 84: 147-151.

5. Danon, D., and Marikovsky, Y. 1964. J. Lab. Clin. Med. 64: 668-674.

6. Fitzgibborns, J.F., Koler, R.D., and Jones, R.T. 1976. J. Clin. Invest. 58: 820-824.

7. Leif, R.C., and Vinograd, J. 1964. Proc. Natl. Acad. Sci. 51: 520-528.

8. Perk, K., and Danon, D. 1965. Res. Vet. Sci. 6: $442-446$

9. Pfeffer, S.R., and Swislocki, N.I. 1976. Arch. Biochem. Biophys. 177: 117-122.

10. Piomelli, S., Lurinsky, G., and Wasserman, L. 1967. J. Lab. Clin. Med. 69: 659-674.

11. Rennie, C.M., Thompson, S., Parker, A.C., and Maddy, A. 1979. Clin. Chim. Acta 98: 119-125.

12. Sass, M.D., Vorsanger, E., and Spear, P.W. 1964. Clin. Chim. Acta 10: 21-26.

13. Valentine, W., Hsieh, H., Paglia, D., Anderson, H., Bangham, M., Jaffe, E., and Garson, O. 1969. New Eng. J. Med. 280: 528-534.

14. Wolowyk, M.W. 1982. pp. 1-11. In: Red Cell Membranes A Methodological Approach. (Ellory, J.C., and Young, J.D. eds.), Academic Press, London.

要約

Percoll 密度何配遠心法によるウシ赤血球の分離：浅野隆司・保刚成男（日本大学農獣医学部獣医薬理学教室） —Percoll のdiscontinuous gradients を用いた密度勾配遠心法によって, ウシ赤血球を 5 分画に分離し，各分 画についてグルコースー6-リン酸脱水素酵素, ピルビン酸キナーゼ, 乳酸脱水素酵素の活性を測定した。比量 の低い分画ほど，各酵素活性は高值を示した。 